\title{
Screening of Wheat (Triticum aestivum L.) Genotypes for Salt Tolerance on the Basis of Physiochemical Characteristics and Bio-Physiological Parameters and Indices
}

\author{
FARZANA SHAHEEN ${ }^{1}$, ZAFAR IQBAL KHAN ${ }^{1}$, TASNEEM AHMAD ${ }^{2}$, \\ MUHAMMAD YASEEN ASHRAF ${ }^{3,4}$, KAFEEL AHMED ${ }^{1}$, SONAINA NAZAR ${ }^{1 *}$, \\ MUHAMMAD NADEEM ${ }^{5}$, SHAHID MAHMOOD ${ }^{5}$, MUHAMMAD UMER FAROOQ AWAN ${ }^{6}$, \\ MONA S ALWAHIBI ${ }^{7}$, MOHAMED SOLIMAN ELSHIKH ${ }^{6}$, \\ MOHAMED RAGAB ABDELGAWWAD \\ ${ }^{1}$ Department of Botany, University of Sargodha, Sargodha, Pakistan \\ ${ }^{2}$ Faculty of Agriculture, Pakki Thatti Research and Development Farms, Toba Tek Singh, Pakistan \\ ${ }^{3}$ Institute of Molecular Biology and Biotechnology (IMBB), The University of Lahore, Pakistan \\ ${ }^{4}$ Nuclear Institute for Agriculture and Biology, (NIAB) Faisalabad, Jhang Road. Pakistan \\ ${ }^{5}$ Institute of Food Science and Nutrition, University of Sargodha, Sargodha, Pakistan \\ ${ }^{6}$ Department of Botany, Govt.College University, Lahore, Lahore, Pakistan \\ ${ }^{7}$ Department of Botany and Microbiology, College of Science, King Saud University, Riyadh 11451, Saudi Arabia \\ ${ }^{8}$ Genetics and Bioengineering, Faculty of Engineering and Natural Sciences, International University of Sarajevo, 71210 \\ Sarajevo, Bosnia and Herzegovina
}

\begin{abstract}
Salt stress is a major threat for growth and development of wheat crop. Screening technique for salinity tolerance is an effective tool to identify tolerant cultivar and high yielding wheat genotypes. Present study was carried out to screen twenty wheat genotypes under laboratory terms utilizing various growth and physiological indices like plant fresh weight stress indices (PFSI), plant height stress tolerance index (PHSI), shoot length stress tolerance index (SLSI), germination stress tolerance index (GSI), plant dry weight stress indices (PDSI), root length stress tolerance index (RLSI), relative water content (RWC). Multivariate techniques like cluster analysis and correlation were used to analyze the variance between wheat genotypes. The correlations analysis indicated significant among different physiological indices like GSI, SLSI, RLSI, PFSI, PDSI and RWC. On the basis of cluster analysis 20 wheat genotypes were classified into three clusters: first cluster included (The genotype WL-711 was the premier scorer followed by Nifa Bathoor, ARRI-II and Millat-11) presents sufficient salt tolerating degree, on the other hand, cluster-2 is comprised of wheat genotypes (Inqilab-91, NIAB-09, Punjab-96, Sehar-2006, Tatara, AS-2002, SA-75, Lasani-09, FSD-08 and Galaxy-13) with medium level of salt tolerance and cluster-3 included genotypes (LU-26-S, Fakhar e Sarhad, Bakhtawar, Punjab-11, Barsat and Kohistan-97) did not perform upto the mark and have lower level of salt tolerance. Correlation analysis among different screening techniques indicated that physiological indices exhibited highly significant and positive correlations among GSI, PHSI, SLSI, PDSI, PFSI, and RWC while nonsignificant correlation existed among PDSI and RLSI. The correlation between PFSI and RWC was significant. Significant correlations between cluster analysis and different indices also proved that salt tolerant wheat genotypes screened.
\end{abstract}

Keywords: Wheat, salt tolerance, correlation analysis, screening

\section{Introduction}

Salinity is one of the important environmental factors that cause soil degradation, limit distribution and productivity of major crops in many regions of the world [1-3]. About 6.3 million hectares out of the 80.0 million hectares or 197.0 million acres (total geographical area of Pakistan) is salt-affected. It includes 0.45 million hectares in Punjab, 0.94 million hectares in Sindh and 0.5 million hectares in NWFP [4]. Plant germination and early seedling growth is mostly limited due to salinity [5]. Firstly,

\footnotetext{
*email: sonaina.nangiana@gmail.com
} 
accumulation of excess amount of salt in the root affects emergence which results in prohibition of growth and development of plants and wheat crop as well [6]. Out of world's total cereal production Wheat (Triticum aestivum L.) constitutes up to $29-30 \%$ and is the third most grown staple food crop of the world population after maize and rice [7-9].

In Pakistan, wheat ranks first as basic food crop and occupies central position in its agriculture based economy as it shares $13.1 \%$ value in agriculture and $2.8 \%$ to gross domestic production of the country [10]. Pakistan is the $6^{\text {th }}$ largest wheat producer because it contributes about $3.58 \%$ of the world wheat production from $4.21 \%$ of the world's wheat growing area. Wheat is commonly classified as a moderately salt tolerant crop as it threshold about $50 \%$ yield loss at $15 \mathrm{dSm}^{-1}$ and zero yield loss at 7 $\mathrm{dSm}^{-1}$ [11-12]. In wheat (hexaploid), the 4D chromosome from Aegilops squarrosa (wild grass) is responsible to tolerate salinity and discriminate $\mathrm{K}^{+} / \mathrm{Na}^{+}$translocation [13]. Evaluating wheat germplasm is necessary to resolve and find genotypes which are tolerant to ionic stress and possess high yield [14]. Different genotypes have been analyzed on basis of physiological indices at germination and early seedling variation in many crop plants [15]. It may leads to recognize varieties which are salt tolerant and are considered as economical exploit variety in future to cultivate it on salt-affected lands. Current study plans to figure out the $\mathrm{NaCl}$ stress of 20 wheat genotypes along with surveying the variability of their genotypic response to salt stress. The objectives of our study to evaluate the worth of several stress indices for identification of genotypes with better performance at different levels of salt stress.

\section{Materials and methods}

\subsection{Experimental design}

This experiment was conducted in lab/greenhouse to determine the salt tolerance in 20 genotype of wheat and 0,80 and $120 \mathrm{mM} \mathrm{NaCl}$ were applied, different physiological indices were used as screening tool. The whole experimentation was operated at NIAB, Plant Stress Physiology Lab, Faisalabad, Pakistan. Twenty local wheat genotypes seeds were used for this study. Healthy seeds of 20 wheat genotypes were surface sterilized by using 3\% sodium hypochlorite solution for $5 \mathrm{~min}$ and washed it for 3 times with distilled water. 10 seeds of each genotype of wheat were grown up in Petri plates moistened with above-mentioned solutions of salinity consisting double layered filter papers. Experiment was carried out in a Growth Chamber (Sanyo-Gallenkamp, UK) running at $28 \pm 2^{\circ} \mathrm{C}$. Germination percentage was recorded when the radical was of $2 \mathrm{~mm}$ in length. After one week of germination, roots and shoots were separated, washed with distilled water and blotted with filter paper.

\subsection{Seed material}

The seeds of twenty local wheat (Triticum aestivumL.) genotypes/lines (NIAB-09, LU-26, Bakhtawar, Kohistan-97, Tatara, Punjab-96, SA-75, NifaBathoor, AS-2002, Fakhar E Sarhad, WL-711, Barsat, Punjab-11, Inqlab-91, Millat-11, ARRI-11, Sehar-06, Galaxy-13, FSD-08 and Lasani -09) were used for conducting the studies. The seed of said cultivars were obtained from research institute NIAB, Jhang road, Faisalabad, Pakistan.

\subsection{Physiological indices}

Following physiological indices were calculated by using following formulae [16]:

- Germination stress tolerance index (GSI) was calculated by

$$
\text { GSI }=\frac{(P I \text { of } \text { stressed seeds })}{P I \text { of control seeds })} \times 100
$$

- Promptness index (PI) was calculated by

$$
\mathbf{P I}=\operatorname{nd} 1(1.00)+\mathrm{nd} 2(0.75)+\mathrm{nd} 3(0.50)+\mathrm{nd} 4(0.25)
$$


- Plant height stress tolerance index (PHSI)

$$
\text { PHSI }=\frac{(\text { Plant height of } \text { stressed } \text { plants })}{(\text { Plant height of control plants })} \times 100
$$

After 14 days of experiment, shoot and root length and fresh weight were calculated. Sample was dried in oven at $70^{\circ} \mathrm{C}$ and noted the dry weight of sample.

- Root length stress tolerance index (RLSI)

RLSI = (Root length of stressed plants / Root length of control plants $) \times 100$

- Shoot length stress tolerance index (SLSI)

SLSI $=($ Shoot length of stressed plants / Shoot length of control plants $) \times 100$

- Plant fresh biomass stress tolerance index (PFSI)

PFSI= (Plant fresh weight of stressed plants / Plant fresh weight of control plants) $\mathrm{x} 100$

- Plant dry biomass stress tolerance index (PDSI)

PDSI = (Plant dry weight of stressed plants / Plant dry weight of control plants) $\mathrm{x} 100$

- Relative water content (RWC)

The formula given by [17] can be used to calculate relative water contents

$\mathbf{R W C}=(\text { fresh weight-dry weight) / (turgid weight-dry weight) }]^{* 100}$

\section{Soil Properties}

Texture of soil and physiochemical parameters ( $\mathrm{pH}, \mathrm{EC}$ and ion contents) are given in Table 1. Characteristics i.e. physiochemical and texture of soil were determined by using methods of [18-19]. Total $\mathrm{N}$ was measured by Kjeldhal method [20]. Sodium and potassium in plant digests sample was analyzed using flame photometer (PFP 7, Jenway). Calcium $\left(\mathrm{Ca}^{2+}\right)$ and magnesium $\left(\mathrm{Mg}^{2+}\right)$ were determined according to the method proposed by Hand Book-60 by Salinity Laboratory Staff US, 1954 [21]. The ground plant material $(1 \mathrm{~g})$ was taken and heated with $15 \mathrm{~mL}$ distilled water in tubes and was placed in oven at $50^{\circ} \mathrm{C}$ for $6 \mathrm{~h}$. The extract was filtered and estimation of chloride by using chloride meter (Corning- 920, Germany).

Table 1. Soil properties of pot experiment

\begin{tabular}{|c|c|}
\hline Characteristics of soil & $\begin{array}{c}\text { Pot Experiment (NIAB, } \\
\text { Faisalabad) }\end{array}$ \\
\hline \multicolumn{2}{|l|}{ Physical } \\
\hline Soil texture & Sandy clay loam \\
\hline Saturation percentage $(\%)$ & 35.5 \\
\hline \multicolumn{2}{|l|}{ Chemical } \\
\hline $\mathrm{EC}_{\mathrm{e}}$ & $0.71-0.96 \mathrm{dS} / \mathrm{m}$ \\
\hline Soil $\mathrm{pH}_{\mathrm{s}}$ & 7.1 \\
\hline Organic matter & $0.31 \%$ \\
\hline $\mathrm{Ca}+\mathrm{Mg}$ & $2.70 \mathrm{meq} / \mathrm{L}$ \\
\hline $\mathrm{CO}_{3}(\mathrm{meq} / \mathrm{L})$ & NIL \\
\hline $\mathrm{HCO}_{3}$ & $3.23 \mathrm{meq} / \mathrm{L}$ \\
\hline $\mathrm{Cl}^{-}$ & $2.4 \mathrm{meq} / \mathrm{L}$ \\
\hline Total N & $0.071 \%$ \\
\hline soluble $\mathrm{K}^{+}$ & $28.0 \mathrm{mg} / \mathrm{kg}$ \\
\hline Available P & $8.54 \mathrm{mg} / \mathrm{kg}$ \\
\hline
\end{tabular}




\subsection{Statistical analysis}

The obtained data was subjected to analysis of variance and Least Significant Difference (LSD) test at $5 \%$ probability level was used to compare the significant means [22]. Comparison of results was statistically analyzed by using the software program statistic 8.1. Minitab-16 was used to describe coefficient of variation analysis and cluster analysis.

\section{Results and discussions}

GSI (Germination stress tolerance index) with significant variations $(\mathrm{p} \leq 0.05)$ unveiled that salinity decreased the seed germination of all wheat genotypes (Table 2). The values of GSI recorded at 80 and $120 \mathrm{mM} \mathrm{NaCl}$ were 81.12 and $76.04 \%$ respectively and reduced with the increase in salinity owing to the significant variation among all salinity treatments (Table 2). At $80 \mathrm{mM} \mathrm{NaCl}$ level Kohistan-97 exhibited less GSI (71.15\%) values while WL-711 (92.75\%) and NifaBathoor $(90.32 \%)$ wheat genotypes exhibited maximum. At $120 \mathrm{mM} \mathrm{NaCl}$ salinity level, WL-711 recorded $81.16 \%$ GSI, while it was $(67.31 \%)$ in Kohistan-97. Overall ranking for GSI have shown that Kohistan-97 was at 20th position whereas WL-711 was at 1st, Barsat covers 2nd and NifaBathoor was found at 3rd position. Salinity significantly minimized plant height of different wheat cultivars which directly influenced the plant height stress tolerance indices. PHSI significantly declined with increase in salt stress levels (84.55 and $71.24 \%$ respectively at 80 and $120 \mathrm{mM} \mathrm{NaCl}$. Variations between all the salinity treatments were significant (Table 3). All wheat cultivars responded differently at $80 \mathrm{mM} \mathrm{NaCl}$ treatment. The maximum PHSI (91.16\%) was observed in WL-711 closely followed by Lasani-09 (90.88\%) while the minimum PHSI was exhibited by Kohistan-97 (59.37\%). At 120mM NaCl treatment, WL-711 (83.14\%) and NifaBathoor (80.56\%) maintained the maximum PHSI closely followed by LU-26 (78.46\%) while the lowest PHSI was observed (47.17\%) again in Kohistan -97. The overall ranking and genotypic means for PHSI indicated that WL-711 positioned at first, NifaBathoor at second and Barsat at third position whereas Kohistan-97 at 20th positions. Salinity influenced the shoot length stress tolerance index (SLSI) by reducing shoot length of all wheat genotypes. SLSI significantly decreased with the increase in salinity level (83.99 and $71.97 \%$ respectively at 80 and $120 \mathrm{mM} \mathrm{NaCl}$ ) (Table 4). The maximum SLSI (92.76\%) was observed in WL-711 closely followed by Bakhtawar (90.86\%) while the minimum SLSI was exhibited by Galaxy-13 (66.75\%). At 120mM NaCl treatment, WL-711 (85.78\%) maintained the maximum SLSI and lowest SLSI was seen again in Galaxy-13 (53.63\%). Genotypic mean clearly indicated that WL-711 gained at first, NifaBathoor was found at second, Barsat was at third rank and Galaxy-13 is at 20th positions. Root length stress tolerance index (RLSI) of each wheat genotypes was affected by salinity stress (71.34\% and 85.18 under 80 and $120 \mathrm{mM} \mathrm{NaCl}$, respectively) (Table 5). RLSI gave significant variations between all salinity levels. The lowest value (50.9\%) for RLSI was observed in Kohistan-97at $80 \mathrm{mM} \mathrm{NaCl}$ treatment, while maximum was exhibited by WL-711 (91.93\%) and FSD$08(91.62 \%)$ closely followed by Lasani-09 $(90.87 \%)$. The highest RLSI value $(81.02 \%)$ was given by WL-711 and the lowest value (38.93\%) was recorded by Kohistan-97 under $120 \mathrm{mM} \mathrm{NaCl}$ salinity stress. On the basis of RLSI genotypic means, WL-711 was ranked first and FSD-08 as 2nd while Kohistan-97 was ranked as 20th. Plant fresh weight significantly reduced under different salinity levels which ultimate influenced plant fresh weight stress tolerance index. PFSI was recorded as 81.79 and $73.92 \%$ under $80 \mathrm{mM}$ and $120 \mathrm{mM} \mathrm{NaCl}$ levels respectively (Table 5). Kohistan-97 and Galaxy-13 exhibited minimum performance for PFSI values (66.76 and $67.98 \%$, respectively) while NifaBathoor and Sehar-2006 maintained similar PFSI $(92.4 \%)$ at $80 \mathrm{mM} \mathrm{NaCl}$ level. Under $120 \mathrm{mM} \mathrm{NaCl}$, WL711(87.63\%) possessed the highest PFSI while Kohistan-97 (54.7\%) and Galaxy-13 (51.3\%) exhibited the minimum PFSI. NifaBathoor and WL-711 scored maximum points for PFSI and was ranked at $1 \mathrm{st}$ and 2nd while Galaxy-13 was at 20th position in whole genotypic means evaluation. Salt stress influenced plant dry weight stress tolerance index (PDSI) and it gradually decreased with increase in salinity levels as 74.44 and $62.02 \%$ PDSI values under levels of 80 and $120 \mathrm{mM} \mathrm{NaCl}$ respectively (Table 5). At $80 \mathrm{mM} \mathrm{NaCl}$ level, PDSI top most value was seen in WL-711 (90.2\%) while minimum PDSI was observed in Inqlab-91 (49.2\%). Maximum PDSI value was recorded for WL-711 (82.71\%) 
while Kohistan-97 (40.04\%) demonstrates poor PDSI at 120mM NaCl level. The whole genotypic scoring for PDSI indicates that WL-711 ranked as first, at second it was Barsat while Kohistan-97and Inqlab-91 were at 19th and 20th positions respectively. Salt stress significantly reduced relative water contents in all wheat cultivars (Table 5) and it gradually decreased as salt stress level increased (82.01and $78.99 \%$ under 80 and $120 \mathrm{mM} \mathrm{NaCl}$ levels, respectively). At $80 \mathrm{mM} \mathrm{NaCl}$ level, maximum RWC $(92.15 \%)$ was observed in WL-711 while minimum RWC (67.61\%) was recorded in Kohistan-97. Maximum RWC (90.69\%) was recorded for WL-711 while Kohistan-97 (62.21\%) and Galaxy-13 (68.24\%) demonstrates poor RWC at $120 \mathrm{mM} \mathrm{NaCl}$ level. On premise of genotypic mean for RWC, WL711 was ranked as first, NifaBathoor as second and Barsat as third while Kohistan-97 was at 20th position. Valid correlations among RLSI, PDSI, SLSI and GSI were calculated by analysis of correlation. Significant and positive correlations were also obtained between GSI, RLSI, SLSI, PFSI and PDSI (Table 6). Results marked as those genotypes were salinity tolerant which high SDSI, SFSI, RDSI, SLSI, and GSI. In present study, wheat genotypes were completely spilt into three clusters based ondendogram (cluster correlation)complete linkage correlation coefficient distance (Figure 1).Cluster-2 consisted of wheat genotypes (NIAB-09, Punjab-96, Sehar-2006, Inqilab-91, Tatara, AS-2002, SA-75, Lasani-09, FSD-08 and Galaxy-13) with moderate salt tolerance capacity and first cluster included (WL-711, NifaBathoor, ARRI-II, Millat-11) exhibited adequate degree of salt tolerance, and genotypes based on cluster-3 (LU-26-S, Fakhar e Sarhad, Bakhtawar, Punjab-11, Barsat and Kohistan-97) did not perform up to the mark and have lower level of salt tolerance. Finding of present study suggest that exploitation of genetic variability for different morphophysiological markers would be beneficial for wheat cultivar development under salt stress. Findings of present study showed that physiological indices can explain some of the mechanisms representing tolerance to salt stress. Aim of wheat breeders is to produce salt tolerant wheat genotypes through technique of screening whereas screened genotypes show versatile performances on different environmental stresses. The conventional fact depict by the tolerance level at seedling stages reflects the tolerance at initial stages such as in wheat and maize [23], sorghum [24] and cotton [25]. Many factors such as condition at the time of harvesting and temperature effect germination. Hence, germination cannot be a good criterion to find out salt tolerance potential of many crop plants [24]. For salt stress, many genotypes are screened on basis of survival of seedlings. Salt stress decreases all physiological indices under salt stress conditions and it also harm cell membrane of seedling which leads to ion homeostasis disturbance [15]. Salt stress decreases all physiological indices under salt stress conditions and affects negatively to growth of radical and plumule. It also harms cell membrane of seedling which leads to ion homeostasis disturbance [26]. Plant fresh and dry weight also decreased under salt stress which ultimately effects PFSI and PDSI [27-28]. Ashraf et al. [1] recorded reduction in absorption of water due to osmotic effects under salinity which lead to adverse results on cell differentiation and division [29-30]. In seedlings, water scarcity results in poor biosynthesis of hormones and plant growth hormones [31]. It is evident that results of present study show that physiological indices like GSI, PHSI, SLSI, RLSI, RWC, PFSI and PDSI were able to utilize to screen germplasm of wheat for salt tolerance. WL-711 genotype was the main scorer for physiological indices followed by NifaBathoor, ARRI-II and Millat-11exhibited adequate degree of salt tolerance which gathered them in 1 cluster dendogram (Figure 1) whereas, cluster-2 consisted of wheat genotypes (Inqilab-91, NIAB-09, Punjab-96, Sehar-2006, Tatara, AS-2002, SA-75, Lasani-09, FSD-08 and Galaxy-13) with medium level of salt tolerance. While wheat genotypes LU-26-S, Fakhar e Sarhad, Bakhtawar, Punjab-11, Barsat and Kohistan-97 did not perform up to the mark and joined them in the cluster 3rd (Figure 1) and mentioned as sensitive. Cluster analysis were used by different researchers to categorized various wheat cultivars on the basis of different characteristics and classified the cultivars within different group based on similarities among them. The closest cultivars were classifies in one group. In current research work, cluster analysis also supported the findings and split the twenty cultivars into three clusters. These results are in accordance with the findings of [16] and [15]. Screening of crop germplasm for stress tolerance by cluster analysis was emphasized in literature [32-34]. These selected genotypes could be used in further breeding programs for salt tolerance. 
Table 2. Impact of salinity levels on different physiological indices

(GSI, PHSI, SLSI) of wheat genotypes

\begin{tabular}{|c|c|c|c|c|c|c|c|c|c|c|c|c|c|c|c|}
\hline \multirow{4}{*}{$\begin{array}{l}\text { Genotypes } \\
\text { NLAB-09 }\end{array}$} & \multirow{2}{*}{\multicolumn{5}{|c|}{$\begin{array}{c}\text { Germination stress tolerance indices } \\
\text { GSI }(\%)\end{array}$}} & \multicolumn{5}{|c|}{ Plant height stress tolerance indices PHSI (\%) } & \multicolumn{5}{|c|}{ Shoot length Stress tolerance indices SLSI (\%) } \\
\hline & & & & & & \multirow{3}{*}{$\begin{array}{c}\text { Ranking } \\
86.65\end{array}$} & \multicolumn{4}{|c|}{ Salinity treatments ( $\mathrm{NaCl}$ in $\mathrm{mM})$} & \multirow{3}{*}{$\begin{array}{c}\text { Ranking } \\
85.8\end{array}$} & \multicolumn{3}{|c|}{ Salinity treatments ( $\mathrm{NaCl}$ in $\mathrm{mM})$} & \multirow{3}{*}{$\frac{\text { Rankine }}{9}$} \\
\hline & \multirow{2}{*}{$\begin{array}{c}80 \mathrm{mM} \\
75\end{array}$} & \multirow{2}{*}{$\begin{array}{c}120 \mathrm{mM} \\
73.21\end{array}$} & \multicolumn{2}{|c|}{ Means } & \multirow{2}{*}{$\frac{80 \mathrm{mM}}{17}$} & & \multirow{2}{*}{$\begin{array}{c}120 \mathrm{mM} \\
72.62\end{array}$} & \multicolumn{2}{|c|}{ Means } & \multirow{2}{*}{$\frac{80 \mathrm{mM}}{11}$} & & \multirow{2}{*}{$\begin{array}{c}120 \mathrm{mM} \\
77.18\end{array}$} & \multicolumn{2}{|c|}{ Means } & \\
\hline & & & 74.11 & HI & & & & 80 & $\mathrm{CDEF}$ & & & & 81.5 & $A B C D E F$ & \\
\hline LU-26 & 85.25 & 78.69 & 81.97 & $\mathrm{BCDE}$ & 6 & 87.06 & 78.46 & 83 & $A B C$ & 4 & 89.7 & 78.62 & 84.14 & $A B C D$ & 5 \\
\hline Inqlab-91 & 73.68 & 68.42 & 71.05 & IJ & 18 & 85.84 & 75.71 & 81 & $\mathrm{BCDE}$ & 8 & 84.1 & 79.98 & 82.04 & $A B C D E F$ & 8 \\
\hline Sehar 2006 & 84.21 & 78.95 & 81.58 & $\mathrm{BCDE}$ & 7 & 87.62 & 73.05 & 80 & $B C D E F$ & 9 & 88.2 & 71.87 & 80.05 & BCDEFG & 10 \\
\hline Bakhtawar & 81.48 & 77.78 & 79.63 & CDEFG & 10 & 59.37 & 47.17 & 53 & I & 20 & 68.3 & 55.87 & 62.1 & $\mathrm{IJ}$ & 19 \\
\hline Kohistan-97 & 71.15 & 67.31 & 69.23 & $\mathrm{~J}$ & 20 & 83.22 & 70.6 & 77 & DEFG & 13 & 90.9 & 80.28 & 85.57 & $A B C$ & 4 \\
\hline Tatara & 77.19 & 73.68 & 75.44 & $\mathrm{GH}$ & 16 & 82.85 & 69.04 & 76 & EFG & 15 & 78.8 & 67.03 & 72.93 & $\mathrm{GH}$ & 16 \\
\hline Punjab-96 & 82 & 78 & 80 & $\mathrm{BCDEF}$ & 9 & 85.81 & 74.35 & 80 & $B C D E F$ & 10 & 87.3 & 80.58 & 83.96 & $A B C D$ & 6 \\
\hline SA-75 & 78.57 & 75 & 76.79 & FGH & 14 & 85.33 & 72.48 & 79 & CDEFG & 12 & 84.8 & 70.22 & 77.5 & DEFG & 13 \\
\hline $\begin{array}{c}\text { NifaBathoo } \\
\text { r }\end{array}$ & 90.32 & 77.42 & 83.87 & $A B C$ & 3 & 89.58 & 80.56 & 85 & $A B$ & 2 & 90.6 & 83.08 & 86.86 & $A B$ & 2 \\
\hline AS 2002 & 83.02 & 77.36 & 80.19 & $\mathrm{BCDEF}$ & 8 & 87.31 & 75.51 & 81 & $B C D$ & 7 & 85.5 & 70.65 & 78.06 & CDEFG & 12 \\
\hline $\begin{array}{c}\text { Fakhar E } \\
\text { Sarhad }\end{array}$ & 80 & 76.36 & 78.18 & DEFGH & 12 & 83.12 & 68.23 & 76 & EFG & 16 & 78.9 & 58.91 & 68.88 & HI & 17 \\
\hline WL-711 & 92.75 & 81.16 & 86.96 & A & 1 & 91.96 & 83.14 & 88 & $A$ & 1 & 92.8 & 85.78 & 89.27 & A & 1 \\
\hline Barsat & 88.33 & 80 & 84.17 & $A B$ & 2 & 87.71 & 77.81 & 83 & $A B C$ & 3 & 89 & 82.34 & 85.68 & $A B C$ & 3 \\
\hline Punjab-11 & 77.78 & 74.07 & 75.93 & FGH & 15 & 83.18 & 64.48 & 74 & G & 18 & 76.2 & 61.05 & 68.63 & $\mathrm{HI}$ & 18 \\
\hline FSD-08 & 84.21 & 80.7 & 82.46 & $B C D$ & 4 & 86.92 & 77.05 & 82 & $B C D$ & 6 & 83.1 & 76.23 & 79.68 & BCDEFG & 11 \\
\hline Millat-11 & 78.95 & 77.19 & 78.07 & EFGH & 13 & 84.36 & 66.06 & 75 & FG & 17 & 80.3 & 69.01 & 74.67 & FGH & 15 \\
\hline ARRI-11 & 80.39 & 78.43 & 79.41 & DEFG & 11 & 87.41 & 66.2 & 77 & DEFG & 14 & 88.9 & 61.8 & 75.36 & EFGH & 14 \\
\hline Galaxy-13 & 73.21 & 67.86 & 70.54 & I & 19 & 74.89 & 57.83 & 66 & $\mathrm{H}$ & 19 & 66.8 & 53.63 & 60.19 & $\mathrm{~J}$ & 20 \\
\hline Lasani-09 & 84.91 & 79.25 & 82.08 & $\mathrm{BCDE}$ & 5 & 90.88 & 74.53 & 83 & $A B C$ & 5 & 90 & 75.29 & 82.67 & $A B C D E$ & 7 \\
\hline Means & 81.12 & 76.04 & & & & 84.55 & 71.24 & & & & 84 & 71.97 & & & \\
\hline
\end{tabular}

Note: Means sharing in same row and column having similar letter did not differ significantly $(\mathrm{p}>0.05)$

Table 3. Impact of salinity levels on different physiological indices

(RLSI, PFSI, PDSI) of wheat genotypes

\begin{tabular}{|c|c|c|c|c|c|c|c|c|c|c|c|c|c|c|c|}
\hline \multirow{4}{*}{$\begin{array}{l}\text { Genotypes } \\
\text { NAB-09 }\end{array}$} & \multicolumn{5}{|c|}{$\begin{array}{c}\text { Root length stress tolerance indices } \\
\text { RLSI (\%) }\end{array}$} & \multicolumn{5}{|c|}{ Plant fresh weight stress tolerance indices PFSI (\%) } & \multicolumn{5}{|c|}{$\begin{array}{c}\text { Plant dry weight stress tolerance indices } \\
\text { PDSI (\%) }\end{array}$} \\
\hline & \multicolumn{4}{|c|}{ Salinity treatments ( $\mathrm{NaCl}$ in $\mathrm{mM})$} & \multirow{3}{*}{$\begin{array}{c}\text { Ranking } \\
15\end{array}$} & \multicolumn{4}{|c|}{ Salinity treatments $(\mathrm{NaCl}$ in $\mathrm{mM})$} & \multirow{3}{*}{$\begin{array}{c}\begin{array}{c}\text { Ranki } \\
\text { ng }\end{array} \\
9\end{array}$} & \multicolumn{4}{|c|}{ Salinity treatments $(\mathrm{NaCl}$ in $\mathrm{mM})$} & \multirow{3}{*}{$\begin{array}{c}\text { Ranki } \\
\text { ng }\end{array}$} \\
\hline & $80 \mathrm{mM}$ & $120 \mathrm{mM}$ & Means & & & \multirow{2}{*}{$\begin{array}{l}80 \mathrm{mM} \\
84.19\end{array}$} & \multirow{2}{*}{$\begin{array}{l}120 \mathrm{mM} \\
76.86\end{array}$} & \multicolumn{2}{|c|}{ Means } & & \multirow{2}{*}{$\begin{array}{c}80 \mathrm{mM} \\
55.32\end{array}$} & \multirow{2}{*}{$\begin{array}{c}120 \mathrm{mM} \\
40.42\end{array}$} & \multicolumn{2}{|c|}{ Means } & \\
\hline & 87.69 & 68.85 & 78.27 & $\mathrm{BCD}$ & & & & 80.53 & $\mathrm{CDE}$ & & & & 47.87 & $\mathrm{H}$ & \\
\hline LU-26 & 84.85 & 78.68 & 81.77 & $\mathrm{ABCD}$ & 8 & 82.4 & 78.03 & 80.22 & $\mathrm{CDE}$ & 10 & 84.34 & 73.63 & 78.99 & $A B C$ & 4 \\
\hline Inqlab-91 & 87.4 & 71.87 & 79.64 & $\mathrm{ABCD}$ & 12 & 81.83 & 71.36 & 76.6 & DEF & 13 & 49.2 & 39.69 & 44.45 & $\mathrm{H}$ & 20 \\
\hline Sehar 2006 & 87.8 & 74.74 & 81.27 & $A B C D$ & 9 & 92.4 & 82.69 & 87.55 & $A B$ & 3 & 77.31 & 58.4 & 67.86 & EFG & 13 \\
\hline Bakhtawar & 50.9 & 38.93 & 44.92 & G & 20 & 66.76 & 54.7 & 60.73 & $\mathrm{H}$ & 19 & 59.82 & 40.06 & 49.94 & $\mathrm{H}$ & 17 \\
\hline Kohistan-97 & 76.09 & 61.52 & 68.81 & F & 19 & 80.7 & 76.59 & 78.65 & CDEF & 12 & 82.92 & 68.66 & .75 .79 & $\mathrm{BCDE}$ & 6 \\
\hline Tatara & 87.23 & 71.78 & 79.51 & $B C D$ & 13 & 83.22 & 78 & 80.61 & $\mathrm{CDE}$ & 8 & 68.54 & 54.97 & 61.76 & $\mathrm{G}$ & 16 \\
\hline Punjab-96 & 84.72 & 69.76 & 77.24 & $\mathrm{CD}$ & 16 & 82.15 & 80.07 & 81.11 & $C D$ & 5 & 73.78 & 59.38 & 66.58 & $\mathrm{G}$ & 14 \\
\hline SA-75 & 86.01 & 74.76 & 80.39 & $A B C D$ & 10 & 81.35 & 67.86 & 74.61 & EFG & 15 & 75.33 & 64.47 & 69.9 & $\mathrm{EF}$ & 12 \\
\hline NifaBathoor & 88.66 & 78.3 & 83.48 & $A B C$ & 5 & 92.4 & 86.45 & 89.43 & A & 2 & 81.37 & 75.32 & 78.35 & $A B C D$ & 5 \\
\hline AS 2002 & 89.13 & 79.92 & 84.53 & $A B$ & 4 & 87.25 & 71.83 & 79.54 & CDEF & 11 & 66.68 & 56.91 & 61.8 & G & 15 \\
\hline Falchar E Sarhad & 86.99 & 77 & 82 & $A B C D$ & 7 & 85.25 & 80.49 & 82.87 & $\mathrm{BC}$ & 4 & 74.04 & 71.34 & 72.69 & CDEF & 8 \\
\hline WL-711 & 91.93 & 81.02 & 86.48 & A & 1 & 91.92 & 87.63 & 89.78 & A & 1 & 90.2 & 80.66 & 85.43 & A & 1 \\
\hline Barsat & 86.62 & 73.51 & 80.07 & $A B C D$ & 11 & 84.1 & 77.23 & 80.67 & $\mathrm{CDE}$ & 7 & 87.3 & 82.71 & 85.01 & A & 2 \\
\hline Punjab-11 & 90.72 & 78.76 & 84.74 & $A B$ & 3 & 76.43 & 70.45 & 73.44 & FG & 17 & 77.65 & 65.22 & 71.44 & CDEF & 10 \\
\hline FSD-08 & 91.62 & 77.96 & 84.79 & $A B$ & 2 & 83.91 & 77.88 & 80.9 & $C D$ & 6 & 80.44 & 63.93 & 72.19 & $\mathrm{CDEF}$ & 9 \\
\hline Millat-11 & 88.43 & 63.95 & 76.19 & $\mathrm{DE}$ & 17 & 78.62 & 69.23 & 73.93 & FG & 16 & 82.96 & 68.43 & 75.7 & $\mathrm{BCDE}$ & 7 \\
\hline ARRI-11 & 86.14 & 70.59 & 78.37 & $\mathrm{BCD}$ & 14 & 75.01 & 65.51 & 70.26 & $\mathrm{G}$ & 18 & 88.68 & 73.88 & 81.28 & $A B$ & 3 \\
\hline Galaxy-13 & 79.98 & 61.1 & 70.54 & $\mathrm{EF}$ & 18 & 67.98 & 51.3 & 59.64 & $\mathrm{H}$ & 20 & 53.77 & 40.04 & 46.91 & $\mathrm{H}$ & 19 \\
\hline Lasani-09 & 90.87 & 73.84 & 82.36 & $A B C D$ & 6 & 77.86 & 74.28 & 76.07 & DEFG & 14 & 79.23 & 62.23 & 70.73 & $\mathrm{DEF}$ & 11 \\
\hline Means & 85.19 & 71.34 & & & & 81.79 & 73.92 & & & & 74.44 & 62.02 & & & \\
\hline
\end{tabular}

Note: Means sharing in same row and column having similar letter did not differ significantly $(\mathrm{p}>0.05)$ 
Table 4. Impact of salinity stress on relative water content (RWC) of different wheat cultivars

\begin{tabular}{|c|c|c|c|c|c|}
\hline \multirow{4}{*}{$\begin{array}{l}\text { Genotype } \\
\text { NIAB-09 } \\
\end{array}$} & \multicolumn{4}{|c|}{ Salinity treatments $(\mathrm{NaCl}$ in $\mathrm{mM})$} & \multirow{4}{*}{$\begin{array}{c}\text { Ranking } \\
17 \\
\end{array}$} \\
\hline & $80 \mathrm{mM}$ & 120Mm & & & \\
\hline & \multicolumn{4}{|c|}{ RWC (\%) } & \\
\hline & 76.82 & 72.38 & 74.60 & LM & \\
\hline LU-26 & 88.00 & 86.53 & 87.27 & $\mathrm{CD}$ & 4 \\
\hline Inqlab-91 & 75.29 & 71.04 & 73.17 & $\mathrm{M}$ & 18 \\
\hline Sehar 2006 & 85.71 & 82.84 & 84.27 & $\mathrm{EF}$ & 7 \\
\hline Kohistan-97 & 67.61 & 62.21 & 64.91 & $\mathrm{O}$ & 20 \\
\hline Bakhtawar & 83.30 & 80.79 & 82.04 & $\mathrm{GH}$ & 10 \\
\hline Tatara & 77.75 & 74.22 & 75.98 & $\mathrm{JKL}$ & 15 \\
\hline Punjab-96 & 83.70 & 80.79 & 82.24 & $\mathrm{GH}$ & 9 \\
\hline SA-75 & 79.22 & 75.16 & 77.19 & JK & 14 \\
\hline Nifa Bathoor & 90.74 & 89.55 & 90.14 & $\mathrm{AB}$ & 2 \\
\hline AS 2002 & 84.53 & 82.47 & 83.50 & FG & 8 \\
\hline Fakhar E Sarhad & 81.19 & 77.95 & 79.57 & $\mathrm{I}$ & 12 \\
\hline WL-711 & 92.15 & 90.69 & 91.42 & A & 1 \\
\hline Barsat & 89.37 & 87.57 & 88.47 & $\mathrm{BC}$ & 3 \\
\hline Punjab-11 & 77.61 & 73.60 & 75.60 & $\mathrm{KL}$ & 16 \\
\hline FSD-08 & 86.90 & 84.76 & 85.83 & $\mathrm{DE}$ & 5 \\
\hline Millat-11 & 78.82 & 76.26 & 77.54 & $\mathrm{~J}$ & 13 \\
\hline ARRI-11 & 82.74 & 79.38 & 81.06 & $\mathrm{HI}$ & 11 \\
\hline Galaxy-13 & 73.22 & 68.24 & 70.73 & $\mathrm{~N}$ & 19 \\
\hline Lasani-09 & 85.55 & 83.33 & 84.44 & $\mathrm{EF}$ & 6 \\
\hline Means & 82.01 & 78.99 & & & \\
\hline
\end{tabular}

Note: Means sharing in same row and column having similar letter differed non-significantly at $p>0.05$

Table 5. Overall screening score of wheat cultivars on the basis of growth and physiological indices

\begin{tabular}{|c|c|c|c|c|c|c|c|c|c|}
\hline Varieties & GSI & PHSI & SLSI & RLSI & PFSI & PDSI & RWC & Scores & Ranking \\
\hline NIAB-09 & 7.41 & 7.96 & 8.15 & 7.83 & 8.05 & 4.79 & 7.46 & 51.65 & 17 \\
\hline LU-26 & 8.20 & 8.28 & 8.41 & 8.18 & 8.02 & 7.90 & 8.73 & 57.71 & 4 \\
\hline Inqlab-91 & 7.11 & 8.08 & 8.20 & 7.96 & 7.66 & 4.45 & 7.32 & 50.77 & 18 \\
\hline Sehar 2006 & 8.16 & 8.03 & 8.01 & 8.13 & 8.76 & 6.79 & 8.43 & 56.29 & 6 \\
\hline Bakhtawar & 7.96 & 7.69 & 8.56 & 6.88 & 7.87 & 7.58 & 8.20 & 54.74 & 10 \\
\hline Kohistan-97 & 6.92 & 5.33 & 6.21 & 4.49 & 6.07 & 4.99 & 6.49 & 40.51 & 20 \\
\hline Tatara & 7.54 & 7.59 & 7.29 & 7.95 & 8.06 & 6.18 & 7.60 & 52.22 & 16 \\
\hline Punjab-96 & 8.00 & 8.01 & 8.40 & 7.72 & 8.11 & 6.66 & 8.22 & 55.12 & 9 \\
\hline SA-75 & 7.68 & 7.89 & 7.75 & 8.04 & 7.46 & 6.99 & 7.72 & 53.53 & 13 \\
\hline NifaBathoor & 8.39 & 8.51 & 8.69 & 8.35 & 8.94 & 7.83 & 9.01 & 59.72 & 2 \\
\hline AS 2002 & 8.02 & 8.14 & 7.81 & 8.45 & 8.74 & 6.18 & 8.35 & 55.69 & 8 \\
\hline Fakhar E Sarhad & 7.82 & 7.57 & 6.89 & 8.20 & 8.29 & 7.27 & 7.96 & 53.99 & 12 \\
\hline WL-711 & 8.70 & 8.75 & 8.93 & 8.62 & 8.98 & 8.54 & 9.14 & 61.66 & 1 \\
\hline Barsat & 8.42 & 8.28 & 8.57 & 8.01 & 8.07 & 8.50 & 8.85 & 58.68 & 3 \\
\hline Punjab-11 & 7.59 & 7.38 & 6.86 & 8.47 & 7.36 & 7.14 & 7.56 & 52.38 & 15 \\
\hline FSD-08 & 8.25 & 8.20 & 7.97 & 8.43 & 8.09 & 7.22 & 8.58 & 56.73 & 5 \\
\hline Millat-11 & 7.81 & 7.52 & 7.47 & 7.62 & 7.39 & 7.57 & 7.75 & 53.13 & 14 \\
\hline ARRI-11 & 7.94 & 7.68 & 7.54 & 7.84 & 7.03 & 8.13 & 8.11 & 54.26 & 11 \\
\hline Galaxy-13 & 7.05 & 6.64 & 6.02 & 7.05 & 5.96 & 4.69 & 7.07 & 44.49 & 19 \\
\hline Lasani-09 & 8.21 & 8.27 & 8.27 & 8.24 & 7.61 & 7.07 & 8.44 & 56.11 & 7 \\
\hline
\end{tabular}


Table 6. Correlation among screening techniques

\begin{tabular}{|c|c|c|c|c|c|c|}
\hline Techniques & GSI & PDSI & PFSI & PHSI & RLSI & RWC \\
\hline PDSI & $0.8551 * *$ & & & & & \\
\hline PFSI & $0.7475 * *$ & $0.4916 *$ & & & & \\
\hline PHSI & $0.7748 * *$ & $0.5190^{*}$ & $0.8234 * *$ & & & \\
\hline RLSI & $0.6126^{*}$ & $0.4386 \mathrm{~ns}$ & $0.6784 * *$ & $0.8737 * *$ & & \\
\hline RWC & $0.9783 * *$ & $0.7912 *$ & $0.7809 * *$ & $0.8421 *$ & $0.6686^{*}$ & \\
\hline SLSI & $0.7394 * *$ & $0.4930 *$ & $0.7709 * *$ & $0.8579 * *$ & $0.5124 *$ & $0.7901 * *$ \\
\hline
\end{tabular}

GSI = Germination stress tolerance index; PHSI = Plant height stress tolerance index; SLSI = Shoot length stress tolerance index;

RLSI $=$ Root length stress tolerance index; PFSI $=$ Plant fresh weight stress tolerance index; PDSI = Plant dry weight stress tolerance index; RWC = Relative water content

$*=$ Significant $(\mathrm{p}<0.05) ; * *=$ Significant $(\mathrm{p}<0.01) ; \mathrm{ns}=$ non-significant $(\mathrm{p}>0.05)$

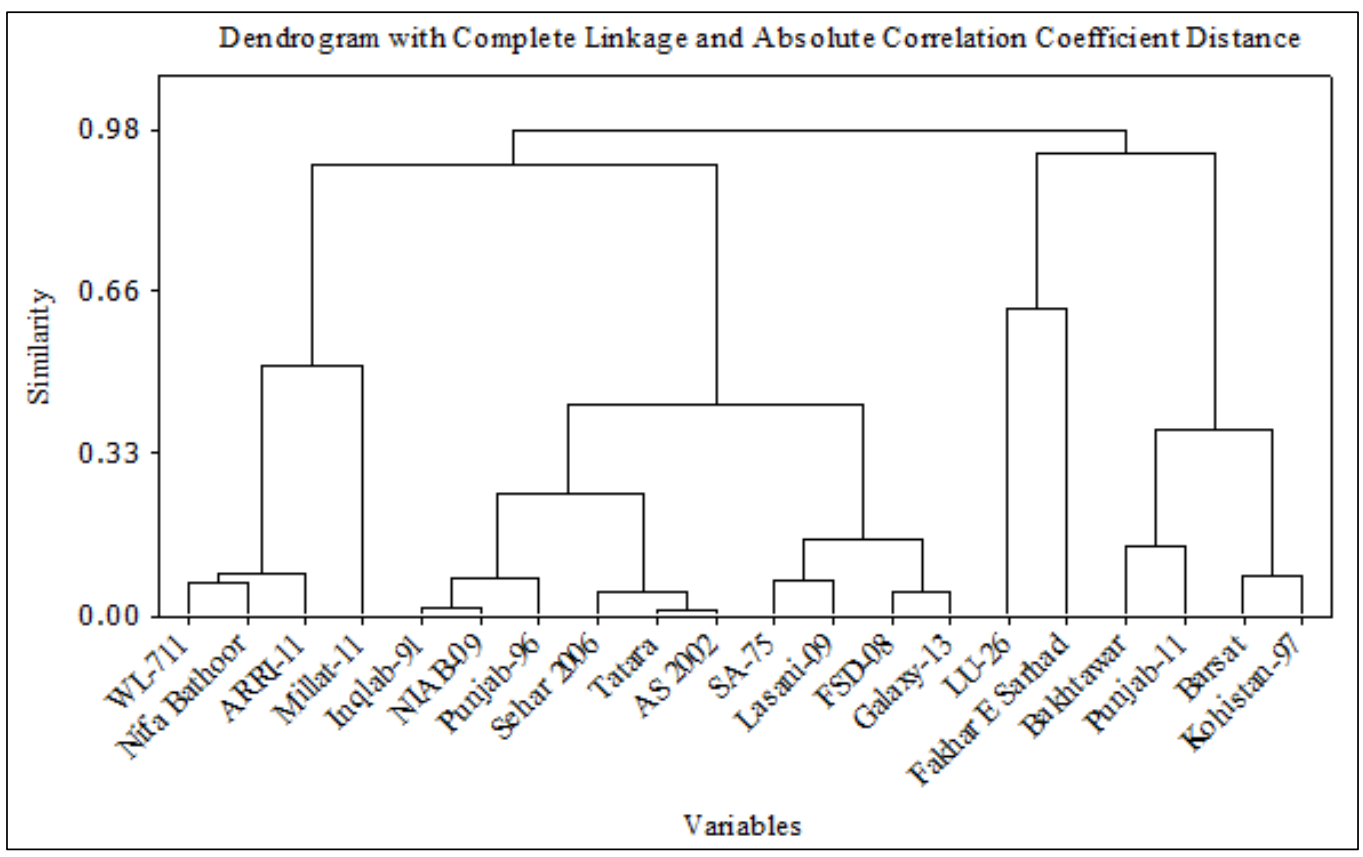

Figure 1. Dandogram from cluster analysis based on physiological indices as a screening tool for salt tolerance in different wheat genotypes. Clusters detail; Cluster: 1 WL-711, NifaBathoor, ARRI-II, Millat-11; Cluster 2: Inqilab-91, NIAB-09, Punjab-96, Sehar-2006, Tatara, AS-2002, SA-75, Lasani-09, FSD-08 and Galaxy-13; Cluster 3: LU-26-S, Fakhar e Sarhad, Bakhtawar, Punjab-11, Barsat and Kohistan-97

\section{Conclusions}

From the results of this study, it was concluded that different wheat genotypes can be screened on the basis of physiological indices for salt tolerance. Significant correlations between cluster analysis and different indices also proved that salt tolerant wheat genotypes screened. Cultivation of these salt tolerant wheat genotypes can be recommended under salt stress conditions and to acquire high yield production. It is further recommended for cultivations of salt tolerant wheat genotypes on normal soil as well on salt affected soil.

Acknowledgments. The authors would like to appreciate the Researchers supporting project number (RSP-2020/173) King Saud University, Riyadh, Saudi Arabia for supporting this work. 


\section{References}

1.ASHRAF, M. Y., AKHTER, K., SARWAR, G., ASHRAF, M., Role of Rooting System in Salt Tolerance Potential of Different Guar Accessions, Agron. Sustain. Dev., 25, 2005, 243-249.

DOI: 10.1051/agro:2005019.

2.RENGASAMY, P., World Salinization with Emphasis on Australia, J. Exp. Bot., 57, 2006, 1017-1023. DOI: $10.1093 / \mathrm{jxb} / \mathrm{erj} 108$.

3.CHANDAN, S., SING, A., BLUMWALD, E., GROVER, A., Beyond Osmolytes and Transporters: Novel Plant Salt-stress Tolerance-related Genes from Transcriptional Profiling Data, J. Plant Physiol., 127, 2006, 1-9. DOI:10.1007/s10142-006-0032-5.

4.FOOD AND AGRICULTURE ORGANIZATION (FAO), Global Network on Integrated Soil Management for Sustainable Use of Salt Affected Soils: FAO Land and Plant Nutrition Management Service, Rome, Italy: 2008, Available online: http://www.fao.org/ag/agl/agll/spush

5.KHAN, M. A., YASMIN, S., ANSARI, R., SHIRAZI, M. U., ASHRAF, M. Y., Screening for Salt Tolerance in Wheat Genotypes at an Early Seedling Stage, Pak. J. Bot., 39, 2007, 2501-2509.

DOI:10.15580/GJSSPN.2019.1.060619105.

6.QAYYUM, B., SHAHBAZ, M., AKRAM, N. A., Interactive Effect of Foliar Application of 24Epibrassinolide and Root Zone Salinity on Morpho-physiological Attributes of Wheat (Triticum aestivum L.), Int. J. Agric. Biol. Sci., 9, 2007, 584-589. DOI: 10.1007/s11099-015-0106-5.

7.SHEWRY, P. R., The Health Grain Programme Opens New Opportunities for Improving Wheat for Nutrition and Health, Nutr. Bull., 34, 2009, 225-231. DOI: 10.1111/j.1467-3010.2009.01747.x

8.ADAMS, M. L., LOMBI, E., ZHAO, F. J., MCGRATH, S. P., Evidence of Low Selenium Concentrations in UK Bread-making Wheat Grain, Food Sci. Agric., 82, 2002, 65.

https://doi.org/10.1002/jsfa.1167.

9.MUJEEB, U. R., SOOMRO, U. A., HAQ, M. Z. U., GUL, S., Effects of NaCl Salinity on Wheat (Triticum aestivum L.) Cultivars, World J. Agric. Sci., 4, 2008, 398-403.

10.ALI, Q., ASHRAF, M., ATHAR, H. R., Exogenously Applied Proline at Different Growth Stages Enhances Growth of Two Maize Cultivars Grown Under Water Deficit Conditions, Pak. J. Bot., 39, 2007, 1133-1144.

11.ROYO, A., ABIO, D., Salt Tolerance in Durum Wheat Cultivars, Span. J. Agric. Res., 1, 2003, 2735 .

12.KHAN, M. H., PANDA, S.K., Alterations in Root Lipid Peroxidation and Antioxidative Responses in Two Rice Cultivars under NaCl Salinity Stress, J. Plant Physiol., 30, 2008, 81-89.

DOI:10.1007/s11738-007-0093-7.

13.SHIRAZI, B., FAZLOLLAHTABAR, H., SHAFIEI, D., A Genetic Approach to Optimize Mathematical Model of Facilities Relocation Problem in Supply Chain, Appl. Sci., 8, 2008, 3119-3128. DOI: $10.3923 /$ jas.2008.3119.3128.

14.JANMOHAMMADI, M., DEZFULIMORADI, P., SHARIFZADEH, F., Seed Invigorations Techniques to Improve Germination and Early Growth of Inbred Line of Maize under Salinity and Drought Stress, Gen. Appl. Plant Physiol., 34, 2008, 215-226.

15.KAUSAR, A., ASHRAF, M. Y., ALI, I., NIAZ, M., ABBASS, Q., Evaluation of Sorghum Varieties / Lines for Salt Tolerance using Physiological Indices as Screening Tool, Pak. J. Bot., 44, 2012, 47-52.

16.ASHRAF, M. Y., HUSSAIN, F., AKHTAR, J., GUL, A., ROSS, M., EBERT, G., Effect of Different Sources and Rates of Nitrogen and Supra Optimal Level of Potassium Fertilization on Growth, Yield and Nutrient, Pak. J. Bot., 40, 2008, 1521-1531.

17.CORNIC, G., Drought Stress and Light Effects on Leaf Photosynthesis. In: Photoinhibition of Photosynthesis (Baker N. R. and Bower J. R., eds.), Bios Scientific Publishers, Oxford, 1994, pp. $297-$ 313. DOI: $10.3923 /$ jbs.2007.841.847.

18.JACKSON, M. L., Chemical Composition of Soil, 1962, pp. 71- 144. In: Chemistry of Soil. F.E. Bean (ed.). Van Nostrand Co., New York. 
19.DEWIS, J., FREITAS, F., Physical and Chemical Methods of Soil and Water Analysis, Soil Bultin., 10, 1970, FAO, Rome.

20.BREMNER, J. M., Nitrogen Availability Indexes, J. Agron., 9, 1965, 1324-1345.

21.***USDA Laboratory Staff., Diagnosis and Improvement of Saline and Alkali Soils. Richards, L.A. (ed.), 1954, Superintendent of Documents US Government Printing Office Washington DC, USA.

22.STEEL, R. G. D., TORRIE, J. H., DEEKEY, D. A., Principles and Procedures of Statistics: A Biometrical Approach. 3rd edition McGraw Hill Book Co. Inc. New York, 1997, pp. 400-428.

https://doi.org/10.1002/bimj.19620040313

23.KHAN, A. A., RAO, S. A., MCNILlY, T. M., Assessment of Salinity Tolerance Based upon Seedling Root Growth Response Functions in Maize (Zea mays L.), Euphyt., 131, 2003, 81-89. https://doi.org/10.15835/nbha47411584.

24.ASHRAF, M. Y., SARWAR, G., Salt Tolerance Potential in Some Members of Brassicaceae. Physiological Studies on Water Relations and Mineral Contents. In: Prospects for Saline Agriculture (Eds.): Ahmad, R. and K.A. Malik. Kluwer Academic Publishers Springer, the Netherlands, 2002, pp. 237-245.

25.AZHAR, F. M., AHMAD, R., Variation and Heritability of Salinity Tolerance in Upland Cotton at Early Stage of Plant Development, Pak. J. Biol. Sci., 3, 2000, 1991-1993.

DOI: 10.3923/pjbs.2000.1991.1999.

26.TAKEL, A., Seedling Emergence and Growth of Sorghum Genotypes under Variable Soil Moisture Deficit, Agron., 48, 2000, 95-102.doi.org/10.5281/zenodo.1080012.

27.ALI, Y., ISLAM, Z., ASHRAF, M. Y., TAHIR, G. R., Effect of salinity on Chlorophyll Concentration, Leaf Area, Yield and Yield Components of Rice Genotypes Grown under Saline Environment, Int. J. Environ. Sci. Technol., 3, 2004, 221-225. DOI:10.1007/BF03325836.

28.BASALAH, M. O., Action of Salinity on Seed Germination and Seedling Growth of Solanum melongena L. Agric. Res., 36, 2010, 64-73.

29.AKHTAR, M., HUSSAIN, F., ASHRAF, M. Y., QURESHI, T. M., AKHTER, J., AWAN, A. R., Influence of Salinity on Nitrogen Transformations in Soil, Commun. Soil Sci. Plant Anal., 43, 2012, 1674 - 1683. DOI:10.1080/00103624.2012.681738.

30.ASHRAF, M. Y., AKHTAR, K., SARWAR, G., ASHRAF, M., Evaluation of Arid and Semi-arid Ecotypes of Guar (Cyamopsis tetragonoloba L.) for Salinity ( $\mathrm{NaCl}$ ) Tolerance, Arid Environ., 52, 2002, 437-482.

31.BOR, M., OZDEMIR, F., TURKSN, I., The Effect of Salt Stress on Lipid Peroxidation and Antioxidants in Leaves of Sugar Beet (Beta vulgaris L.) and wild beet (Beta maritima L.), Plant Sci., 164, 2003, 77-84.

32.VAHADATI, K., LOTFI, N., KHOLDEBARIN, B., HASSANI, D., AMIRI, R., MOZAFFARI M. R., LESLIE, C., Screening for Drought Tolerant Genotypes of Persian Walnuts (Juglans regia L.) During Seed Germination, Hortsci., 44, 2009, 1815-1819.

33.FARSHADFAR, E., ELYASI, P., Screening Quantitative Indicators of Drought Tolerance in Bread Wheat (Triticum aestivum L.) Landraces, Europ. J. Exp. Bio., 2, 2012, 577-584.

34.NOORIFARJAM, S., FARSHADFAR, E., SAEIDI, M., Evaluation of Drought Tolerant Genotypes in Bread Wheat Using Yield Based Screening Techniques, Europ. J. Exp. Bio., 3, 2013, 138-143.

$\overline{\text { Manuscript received: } 4.03 .2021}$ 